\title{
Maize Seed Production Under Climate-Smart Agriculture Techniques as a Response to Climate Change Effects
}

\author{
Blair Moses Kamanga ${ }^{1, *}$, Thomas Mpiluwa ${ }^{1}$, Courage Yaw Krah², Akeme Cyril Njume², Nadiya Ifti- \\ wata Rahmah $^{3}$ \\ ${ }^{1}$ Department of Agriculture Research, Pesticides Control Board, Bvumbwe Agricultural Research Station, P.O. Box 51300, Limbe, \\ Malawi. \\ ${ }^{2}$ Department of Mechanical and Biosystems Engineering, IPB University, Bogor, Indonesia. \\ ${ }^{3}$ Department of Agronomy and Horticulture, IPB University, Bogor 16680, Indonesia.
}

\begin{abstract}
How to cite this paper: Blair Moses Kamanga, Thomas Mpiluwa, Courage Yaw Krah, Akeme Cyril Njume, Nadiya Iftiwata Rahmah. (2020) Maize Seed Production Under Climate-Smart Agriculture Techniques as a Response to Climate Change Effects. International Journal of the Science of Food and Agriculture, 4(3), 249-255.

DOI: $10.26855 /$ ijfsa.2020.09.004
\end{abstract}

Received: May 9, 2020

Accepted: June 22, 2020

Published: July 29, 2020

*Corresponding author: Blair Moses Kamanga, Department of Agriculture Research, Pesticides Control Board, Bvumbwe Agricultural Research Station, P.O. Box 51300, Limbe, Malawi.

Email: blairkamanga@gmail.com

\begin{abstract}
Field experiments were conducted to evaluate the response of climate-smart agriculture (CSA) techniques to effects of climate change, i.e., dry spells on maize seed production. The trials evaluated growth characteristics, yield, and seed quality parameters. CSA techniques such as minimum tillage with dead mulch, zero tillage with mulch, minimum tillage with roundup, pit planting, zero tillage with live cover and control (conventional farming) were laid off in RCBD with four replicates. Results indicated that CSA techniquessignificantly increased plant height, the number of leaves, leaf area, leaf area index, total dry matter accumulation, yield and yield components even though the cropping season was associated with prolonged dry spells. Maize seed grown under minimum tillage with dead mulch (maize stover as a cover) significantly increased production of maize seed with dry cob yield (8.92 ton ha ${ }^{-1}$ ), seed grain yield (4.45 ton ha ${ }^{-1}$ ), 1000-seeds weight (386.9g), and highest germination percentage, seed vigor index and germination energy of 1,127 and $80.24 \%$, respectively. Maize seed can be produced under climate-smart agriculture techniques and still maintain high seed quality than under conventional system.
\end{abstract}

\section{Keywords}

Germination Rate, Seed Vigour Index, Leaf Area Index, Minimum tillage, mulching, Zero tillage

\section{Introduction}

Maize (Zea mays L.) is the most important grain crop in Southern Africa and is produced throughout the region under diverse environments. It is produced on average land of $65 \%$ of total arable land [1]. Maize production can be successfully produced if the correct production inputs are applied that can sustain the environment. Basically, production inputs may include good quality seed, adapted cultivars, correct plant population, and applying appropriate agronomic practices.

The production of good quality seed under harsh conditions has a detrimental effect more especially if the dry spell occurs during the grain filling stage. Due to the increase in temperature in combination with more severe and predominantly droughts or dry spells, have profoundly reduced soil water available for plant use. Studies have shown that soil moisture will decline by $25 \%$ in southern Africa due to more and frequent droughts [2]. Increasing temperatures have shorten the crop growth period and increase plant water potential demands through higher transpiration rates, thereby potentially reducing plant production[3, 4]. Furthermore, increasing temperatures have directly affected crop production 
through heat waves, and this has large impact on crop production more especially when coupled with low soil moisture during grain filling and can eventually affect final seed quality [5].

The concepts of CSA have been developed based on conventional agricultural systems, CSA may include pit planting, zero or minimum tillage, maintenance of soil cover through a cover crop or mulching with dead or live cover crop and crop rotation [6]. Since its introduction by the FAO of the United Nations, CSA has been accepted as one of the agricultural innovations that delivers one or more of the three pillars of conservation farming. The use of conservation agriculture has been driven by increased soil degradation more especially in the tropics and subtropical areas where crop yield is relatively lower due low soil organic matter, limited use of fertilizer and recurrent droughts [7] [8]. Pit planting has been developed from indigenous knowledge, the technique is a climate-smart soil and water conservation technology [8] [9]. It basically involves digging pits that are 20-40 cm diameter and $10-15 \mathrm{~cm}$ depth to accumulate and store water during plant growth with or without the application of organic manure, plant residues and or animal manure [10].

As climate change effects intensify, unpredictable rainfall patterns, frequent droughts, run-off, and rising temperatures affect agricultural production. Therefore, reducing or minimizing tillage activities and maintain adequate soil cover through mulching provide multiple benefits to a farmer in dealing with climate related risks. Some of the benefits include reduced run-off, increased water infiltration, improve soil organic matter and soil moisture retention thereby maintaining smooth plant growth during dry spells [11]. The effects of high temperatures and soil water deficit have been studied and they cause a great reduction in yield and quality [5]. However, drought/dry spells and heat stress occur concurrently in a production system, and their combined effects on crop development and growth are less understood in as far as maize seed production is concerned. Therefore, analysis of different climate-smart agriculture techniques was carried out to identify and characterize techniques that have high productivity and stress resistance towards maize seed production and maintaining final maize seed quality under current climatic change conditions.

\section{Materials and methods}

\subsection{Location}

The study was conducted in Chipala Extension Planning Area located at Latitude -13 $01^{\prime} 60.00^{\prime \prime} \mathrm{S}$ and Longitude $33^{\circ} 28^{\prime}$ 59.99" E Kasungu district, Malawi in 2017/18 growing season. Kasungu District has a warmer tropical climate characterized by a unimodal rainfall pattern, it receives erratic rains between $500-1,200 \mathrm{~mm}$ per annum. The district is located at an attitude of 1,300 meters above sea level, with undulating landscape and an annual minimum temperature of $19-23^{\circ} \mathrm{C}$ of which in the recent years has risen to up to $31^{\circ} \mathrm{C}$ due to climate change. The area has predominantly oxisols, ultisols, and alfisols soils which are fertile with substantial potential for maize production [5].

\subsection{Experimental design}

The experiment was arranged in a randomized complete block design (RCBD), replicated four times with individual plot sizes of $6 \mathrm{~m} \times 5 \mathrm{~m}\left(30 \mathrm{~m}^{2}\right)$. A composite maize cultivar ZM621which was sourced from Chitedze research seed bank was used in this experiment. The seed was planted on the $6^{\text {th }}$ December 2018 spaced at $75 \mathrm{~cm} \times 25 \mathrm{~cm}$. One maize seed was sown per planting station and was later supplied where it did not emerge.

\subsection{The experimental treatments}

\subsubsection{Convectional/Farmer's practice (control treatment)}

Treatment plots were tilled manually using a hand hoe for ridge preparation without the use of additional external inputs. Weeds were controlled by handhoe twice after maize emergence [5].

\subsubsection{Zero tillage with Live cover mulch}

Treatment plots were not tilled. Arachis pintoi accession CIAT 18744 was used as a cover crop that was sourced from Bunda college. Arachis was planted on $2^{\text {nd }}$ December at the onset of the rain season, spaced at $20 \mathrm{~cm} \times 20 \mathrm{~cm}$ (one seed per hole) two weeks prior to maize planting. Arachis was maintained as permanent live ground cover for the duration of the experiment until harvesting of maize.

\subsubsection{Zero tillage with roundup}

Treatment plots were not tilled; however, previous ridges were used to plant maize seed. Roundup was used to kill weeds, and later the seed was planted [29].

\subsubsection{Zero tillage with dead mulch}

Maize stover from the previous harvest were used to cover the soil, at least a $10-15 \mathrm{~cm}$ thickness was used to make sure that the soil is not exposed [30].

\subsubsection{Minimum tillage with dead mulch}

The land was tilled with the hoe at an estimated depth of $15-25 \mathrm{~cm}$, maize stover of the previous growing season was 
used to cover the soil.

\subsubsection{Pit planting}

Pits were dug measured $20-40 \mathrm{~cm}$ in length and $10-15 \mathrm{~cm}$ depth to accumulate and store water during plant growth without the application of organic manure, plant residues and animal manure [10] as in other treatments. Basically, four seeds were planted in each pit at the corner of the pit. Other agronomic practices such as weeding, fertilizer application and isolation distance for OPV varieties were maintained.

Determination of growth, yield, and seed quality parameters which include; plant growth parameters such as plant height $(\mathrm{cm})$, number of leaves, leaf area per plant $\left(\mathrm{cm}^{2}\right)$ leaf area index (LAI) and total dry matter $\left(\right.$ ton $\left.\mathrm{h}^{-1}\right)$. Total dry matter (TDM) was determined by oven-drying packed in a brown envelope at a fixed temperature of $75^{\circ} \mathrm{Cuntil}$ constant weight was attained [12]. Seed quality determinants such as vigor index, mean germination time (MGT), germination rate and germination \% were all determined.

\subsection{Statistical analysis}

The data analyses were carried using R Statistical [28] and analysis of variance was carried out on each observation on the treatments. The differences between means were separated by DMRT at 0.05 level of significance.

\section{Results and discussion}

\subsection{Maize growth characteristics under different climate-smart agriculture technologies}

There were significant differences in maize seed growth characters under different CSA techniques (Figure 1) and results indicated that plant height and the number of leaves grown under minimum tillage with dead mulch were significantly higher as compared to conventional farming and other technologies. Furthermore, results on leaf area per plant $(1,985.32 \mathrm{~cm})$ and Leaf Area Index (LAI) 1.954 significantly increased under climate-smart agriculture techniques as compared to the control (conventional farming). Plant height was increased even though the growing season was characterized by two prolonged dry spells which occurred during vegetative and tasseling stage which significantly affected plant growth parameters under conventional seed production. However, maize plants reached their height potential under CSA techniques due to availability of moisture in the soil.

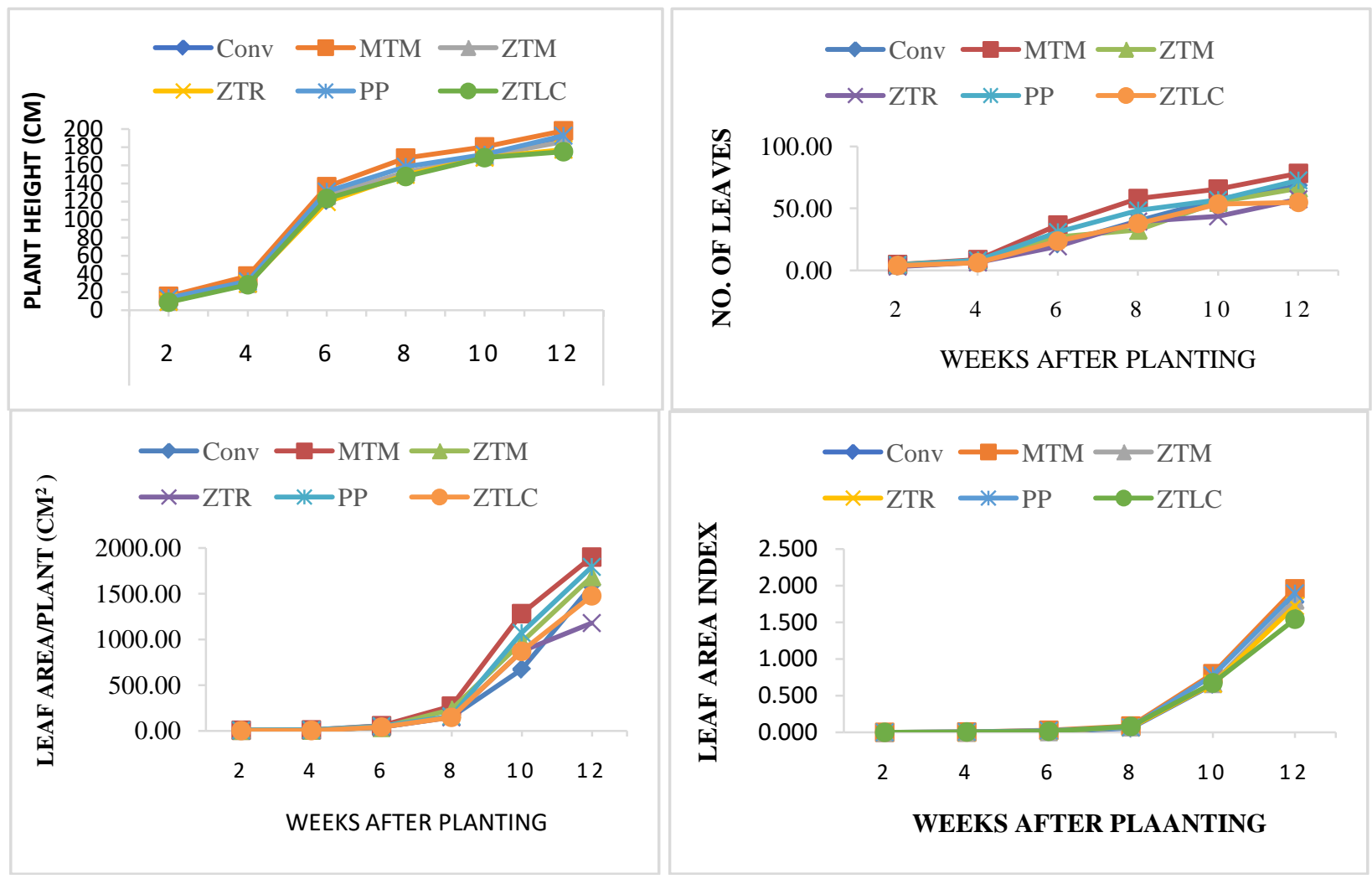

(MTM = Minimum tillage with mulching, PP = Pit planting, ZTR = Zero tillage with roundup, Conv = conventional farming, ZTLC = zero tillage with live cover shrub, ZTM zero tillage with mulching)

Figure 1. Maize crop growth characters under different climate-smart agriculture technologies. 
Plant height was significantly influenced by moisture stress at different growth stages as a result of dry spells that occurred during the growing season. The results indicated that plant height was reduced on the conventional method of seed production because of water stress due to dry spells that occurred during the development stage. This confirms that plant height was affected by the amount of moisture content available in the soil. LAI (Figure 1) of maize seed grown under minimum tillage with dead mulch was not affected (0.032) which was significantly higher than the control. The leaf area index of a crop with adequate water supply at elevated carbon dioxide concentration increases and there israpid leaf production at the vegetative growth phase due to the availability of moisture in the soil [13].

Leaf area per plant was significant in both $6^{\text {th }}$ to $12^{\text {th }}$ week due to the response of dry spell (Figure 1). Minimum tillage with dead mulch had significantly higher leaf area per plant $\left(268.14 \mathrm{~cm}^{2}\right)$ as compared to conventional farming $\left(150.39 \mathrm{~cm}^{2}\right)$ in the $8^{\text {th }}$ week. Furthermore, pit planting plants had relatively higher leaf area $\left(1,071.92 \mathrm{~cm}^{2}\right)$ as compared to other treatments with zero tillage with live cover and conventional farming having the least of 868.58 and 672.39 respectively. Research has shown that a deficit of water decreases cell division and cell proliferation which results in poor leaf development and eventually generates lower grain yield [14]. In this research, dry spells could be the main cause of water stress in different treatment, basically underwater stress the percentage of leaf development decline significantly [15], that resulted in low accumulation of biomass.

\subsection{Yield and yield components of maize seed grown under different CSA technologies}

The yield components under various CSA techniques were significant $(\mathrm{p}<0.05)$ except the harvesting index. The result combined in (Table 1) shows that the Minimum tillage with mulching treatment had significant higher TDM, DCY, GY, cob length and TGY per hectare with the 12.28 tons ha ${ }^{-1}, 7.42$ ton ha ${ }^{-1}, 559$ grams per ear, $19.03 \mathrm{~cm}$ and 6.16 ton $\mathrm{ha}^{-1}$ respectively. However, harvesting index had statistically similar results with MTM having 0.50 which was slightly higher than the rest of the treatments.

The analysis of variance for the mean revealed that maize yield and yield components significantly increased $(\mathrm{P}<0.05)$ under the climate-smart agriculture method more especially MTM because it was able to retain moisture during the period of dry spells except for harvesting index which was not significant ( $p>0.05$ ). The present results, however, are in line with the findings of [17] and [15], who indicated that the availability of moisture in the soil during dry spells increases maize yield components and yield.

Table 1. Maize seed grain yield and yield components under different maize seed cultivation systems

\begin{tabular}{|c|c|c|c|c|c|c|}
\hline CSA & TDM (t ha' $\left.{ }^{-1}\right)$ & DCY (t ha' $\left.{ }^{-1}\right)$ & GY $\operatorname{Cob}^{-1}(\mathrm{~g})$ & Cob Length (cm) & TGY (t ha' $\left.{ }^{-1}\right)$ & HI \\
\hline Conv & $7.73^{\mathrm{a}}$ & $4.36^{\mathrm{ab}}$ & $250.2^{\mathrm{a}}$ & $9.68^{\mathrm{a}}$ & $3.66^{\mathrm{a}}$ & 0.48 \\
\hline ZTM & $8.03^{\mathrm{a}}$ & $4.57^{\mathrm{ab}}$ & $276.3^{\mathrm{a}}$ & $13.26^{\mathrm{b}}$ & $3.57^{\mathrm{a}}$ & 0.47 \\
\hline ZTLC & $7.05^{\mathrm{a}}$ & $4.83^{\mathrm{ab}}$ & $288.2^{\mathrm{ab}}$ & $13.82^{\mathrm{b}}$ & $3.25^{\mathrm{a}}$ & 0.49 \\
\hline ZTR & $7.20^{\mathrm{a}}$ & $3.97^{\mathrm{a}}$ & $278.4^{\mathrm{a}}$ & $13.95^{\mathrm{b}}$ & $2.95^{\mathrm{a}}$ & 0.40 \\
\hline PP & $8.94^{\mathrm{ab}}$ & $5.14^{\mathrm{ab}}$ & $338.0 b^{c}$ & $18.54^{\mathrm{C}}$ & $4.19^{\mathrm{ab}}$ & 0.46 \\
\hline MTM & $12.28^{\mathrm{b}}$ & $7.42^{\mathrm{b}}$ & $359.6^{c}$ & $19.03^{c}$ & $6.16^{\mathrm{b}}$ & 0.50 \\
\hline Fpr & $* *$ & $* *$ & $* *$ & $* *$ & $* *$ & ns \\
\hline CV(\%) & 12.5 & 21.6 & 9.6 & 9.3 & 19.1 & 18.1 \\
\hline
\end{tabular}

Note: $* *=$ significant, $\mathrm{ns}=$ not significant, CSA $=$ Climate Smart Agriculture, TDM = Total Dry Matter, DCY $=$ Dry Cob yield, GY $=$ Grain

Yield, TYG = Total Grain Yield, and HI = Harvesting Index, means with the similar superscript letter are not significant at 0.05 level of signi-

ficance. $\mathrm{MTM}=$ Minimum tillage with mulching, PP = Pit planting, ZTR = Zero tillage with roundup, Conv = conventional farming, ZTLC =

zero tillage with live cover shrub, ZTM zero tillage with mulching.

Research has shown that soil moisture content control plant phenological, physiological and morphological characteristics of maize plant in response to water stress induced by either drought or dry spells [16], basically when water at field capacity decreases, this initiates a decrease on a number of grains per plant and yield per unit area [17] and number of cobs per plant decreases, to concur with these findings, maize seed that was grown using conventional farming system yielded short corn-cob in length $(9.68 \mathrm{~cm})$ and, cob grain yield per ear per plant, which was significantly lower than that of minimum tillage with mulch. Minimum tillage with mulch treatment was able to retain moisture in the soil than unmulched treatment, the mulch treatment improves soil moisture and stores water hence improved plant growth characteristics and improved yield and its components. This implies that the grain yield and yield components increased significantly due to the availability of moisture in the soil.

In connection to this research other studies have revealed that substantial improvements in yields of major crops such sorghum and maize have been witnessed by smallholder farmers [18]. There is adequate evidence that CSA increases the biological yield of major crops even on poor soils and offers economic benefits from diversified crop rotation sys- 
tem due to adaptability and productivity because of soil cover [19] and mulching that enhance soil moisture retention [20].

\subsection{Seed quality analysis produced under different climate-smart agriculture production systems}

Seed vigor which determines the level of activity and performance of the seed or seed lot during germination and seedling emergence was assessed (Table 1).There were significant differences in seed quality produced on different climate smart-agriculture technologies. MTM and PP produced vigorous seedling $(1,127.0$ and 1,117.5) which were significantly higher than the rest of the treatments with seeds produced from ZTR, Conv and ZTLC which were less vigorous having 843.0, 766.0, and 788.8, respectively. Germination was significant with PP (98\%) and Conv and ZTLC which was significantly lower having $92.5 \%$ and $90 \%$ respectively. Furthermore, significant differences were observed in GR, GW, and GE with seed produced under MTM and PP having statistically higher GR, GW and GE as compared to control treatment (Conv). Furthermore, there were no significant differences in MGT (days) among the treatments, however, MTM germinated earlier (2.39) days as compared to Conv and ZTR having 3.46 and 3.66 days, respectively.

Table 2. Seed quality analysis produced under different climate-smart agriculture production systems

\begin{tabular}{|c|c|c|c|c|c|c|}
\hline CSA & SVI & GP\% & GR & MGT (D) & GW(1000)g & GE \\
\hline MTM & $1127.0^{\mathrm{a}}$ & $96.80^{\mathrm{ab}}$ & $22.61^{\mathrm{a}}$ & 2.39 & $386.90^{\mathrm{a}}$ & $84.82^{\mathrm{a}}$ \\
\hline PP & $1117.5^{\mathrm{a}}$ & $98.50^{\mathrm{a}}$ & $18.93^{\mathrm{ab}}$ & 2.71 & $379.70^{\mathrm{ab}}$ & $80.00^{\mathrm{ab}}$ \\
\hline ZTR & $843.0^{\mathrm{bc}}$ & $92.25^{b c}$ & $14.77 b$ & 3.66 & $335.40^{c}$ & $75.00^{\mathrm{ab}}$ \\
\hline Conv & $766.0^{c}$ & $92.25^{\mathrm{bc}}$ & $14.85^{\mathrm{b}}$ & 3.46 & $347.47^{\mathrm{c}}$ & $74.58^{\mathrm{ab}}$ \\
\hline ZTLC & $788.8^{\mathrm{c}}$ & $90.50^{c}$ & $15.55^{\mathrm{b}}$ & 3.38 & $369.30^{\mathrm{abc}}$ & $72.78^{\mathrm{ab}}$ \\
\hline ZTM & $1018.0^{\mathrm{ab}}$ & $95.00^{\mathrm{abc}}$ & $16.38^{\mathrm{ab}}$ & 3.61 & $364.0^{\mathrm{abc}}$ & $70.75^{\mathrm{b}}$ \\
\hline $\mathrm{P}$-value & $* *$ & $* *$ & * & ns & $* *$ & $* *$ \\
\hline $\mathrm{CV} \%$ & 27.74 & 4.25 & 25.12 & 24.7 & 10.96 & 12.11 \\
\hline
\end{tabular}

Note. CSA = climate-smart agriculture, SVI = Seedling Vigour Index, GR = Germination rate, MGT = mean germination time, GW = Grain weight, GE = Germination energy, MTM = Minimum tillage with mulching, PP = Pit planting, ZTR = Zero tillage with roundup, Conv = conventional farming, ZTLC = zero tillage with live cover shrub, ZTM zero tillage with mulching. Means with similar superscript are not significant at 0.05 level of significance.

The scarcity of water is a severe environmental restriction to plant productivity. Crop growth and yield parameters are negatively affected by inadequate water supply due to physical damages, physiological disruptions, and biochemical changes. Good seed quality is important in any cropping system because it plays an important role in the early growth stages of agricultural crops [21]. Good quality seed will enable better field performance in terms of germination, rapid emergence, and vigorous seedling growth [22]. Furthermore, Schussler and Westgate [23] indicated that reduced photosynthetic activity leads to poor seed set in plants grown in pots and contributes to poor quality seed. Furthermore, results in this research are in accordance with [17] who indicated that under water stress the percentage of germination of seed produced declined significantly which might have contributed to the nature of seed produced on conventional farming system.

Generally, droughts have been associated with heatwaves, i.e., transient increase in temperature above normal levels lasting from days to weeks [24]. Basically, the combination of moisture deficit and heat stress will have a profound implication on food security through its effects on crop growth and water use efficient by crops [25]. Maize production mainly depends on rain fed because more than $70 \%$ of global arable land is under rain fed agriculture, which means that maize seed production mainly depends on natural rains. Temporal and/or spatial variations in precipitation commonly known as dry spells associated with climatic change [26] in addition with the converging pressures on population growth and increased urbanization has reduced the availability of freshwater for irrigation [27] which become more difficult to use more especially by smallholder farmers who play a major role in seed production.

\section{Conclusion}

Results in this study has revealed that different CSA agricultural technology more especially minimum tillage with dead mulch and pit planting can maximize good quality seed production in the presence of prolonged dry spells during both vegetative and reproductive stages of maize seed production. However, this kind of research should be repeated in different regions with a wide variation in rainfall patterns using different varieties of hybrid maize seed in order to quantify and adopt the production systems. 


\section{Acknowledgments}

The authors would like to acknowledge the Chitedze Agricultural Research Station for the provision of seed and maize seed producers in Kasungu district for the provision of land and supervisory services rendered during the research period.

\section{References}

[1] FAO. (2013). Climate-smart Agriculture Sourcebook. Rome, Italy: Food and Agricultural Organization of the United Nations.

[2] Fraser, E. D. G., Simelton, E., Termansen M., Gosling S. N. and South A. (2013). "Vulnerabilityhotspots": integrating socio-economic and hydrological models to identify where cereal production may decline in the future due to climate change-induced drought. Journal of Agricultur and Forest, 170, 195-205.

[3] Ludwig, F. and Asseng, S. (2006). Climate change impacts on wheat production in theMediterranean environment in Western Australia. Agricultural Systems, 90: 159-179.

[4] Springate, D. A. and Kover, P. X. (2014). Plant responses to elevated temperatures: a field study onphenological sensitivity and fitness responses to simulated climate warming. Global Change Biology, 20, 456-465.

[5] GAP. (2014). Guide to Agriculture Production in Malawi. Lilongwe: Ministry of Agriculture and Food Security.

[6] Giller, K. E., Witter, E., Corbeels, M. and Tittonell, P. (2009). Conservation agriculture and smallholderfarming in Africa: the heretics’ view. Field Crops Research, 114, 23-34.

[7] Buah, S. S. J., Ibrahim, H., Derigubah, M., Kuzie, M., Segtaa, J. V., Bayala, J., Zougmore, R. and Ouedraogo, M. (2017). Tillage and fertilizer effect on maize and soybean yields in the Guinea savanna zoneof Ghana. Agriculture and Food Security, 6(1), 1-7.

[8] Lahmar, R., Bationo, B. A., Lamso, N. D., Guero, Y., and Tittonell, P. (2012). Tailoring conservation agriculture technologies to West Africa semi-arid zones: building on traditional local practices for soil restoration. Field Crops Research, 132, 158-167.

[9] Masse, D., Hien, E., Kabore, T., Bilgo, A., Hien, V., and Chotte, J. L. (2011). Evaluation of farming practicesin sub-Saharan region confronted by demographic and climatic changes: runoff control andorganic matter resources management. Procedia Environmental Science, 9, 124-129.

[10] Sawadogo, H. (2011). Using soil and water conservation techniques to rehabilitate degraded lands in northwestern Burkina Faso. Internatinal Journal of Agriculture Sustainability, 1(9), 120-128.

[11] Obalum, S. E., Igwe, C. A. and Obi, M. E. (2012). Soil moisture dynamics under rainfed sorghum andsoybean on contrasting tillagemulch seedbeds in a mineral sandy loam at derivedsavanna ofsouth-eastern Nigeria. Archives of Agronomy and Soil Science, 11(58), 1205-1227.

[12] ISTA. (2014). International Rules for Seed Testing. International Seed Testing Association Bassersdorf, Switzerland.

[13] Grashoff, C., Dijkstra, P., Nonhebel, S., Schapendonk, A. H. C. M., and Van de Geijn, S. C. (1995). Effects of climate change on the productivity of cereals and legumes, model evaluation of observed year-to-yearvariability of the CO2 response. Global Change Biology, 1(6), 417-428.

[14] Muhammad, A., Muhammad, A. M., and Cengiz, R. (2015). Drought stress in maize (Zea mays L.) effects, resistance mechanisms, global achievements and biological strategies for improvement. Springer, Netherland, 1, 1-75. doi:10.1007/978-3-319-25442-5.

[15] Karasu, A., Kuscu, H. and Öz, M. and Bayram, G. (2015). The effect of different irrigation water levels on grain yield, yield components and some quality parameters of silage Maize in the Marmara region of Turkey. Notulae Botanicae Horticulture Agrobotanici Clujeană-Napoca, 1(43), 138-145. doi: 10.15835/nbha4319602.

[16] Khan, M. B., Hussain, N., and Ii, M. (2001). Effects of water stress on growth and yield components of maize Variety YHS202. Journal of Research (science), 12(1), 15-18.

[17] Mansouri, C., Modarres, S. A. and Saberali, S. F. (2010). Maize yield response to deficit irrigation duringlow-sensitive growth stages and nitrogen rate under semi-arid climatic conditions. Agricultural Water Management, 97(1), 12-22.

[18] Wildemeersch, J. C., Timmerman, E., Mazijn, B., Sabiou, M., Ibro, G., Garba, M. and Cornelis, W. (2015a). Assessing the constraints to adopt water and soil conservation techniques in Tillaberi, Niger. Land Degradation and Development, 5(26), 491-501.

[19] Giller, K. E., Witter, E., Corbeels, M., and Tittonell, P. (2009). Conservation agriculture and smallholder farming in Africa: The heretics’ view. Field Crops Research, 114, 23-34.

[20] Bayala, J., Sileshi, G. W., Coe, R., Kalinganire, A., Tchoundjeu, Z., Sinclair, F., and Garrity, D. (2012). Cereal yield response to conservation agriculture practices in drylands of West Africa: a quantitative synthesis. Journal of Arid Environment, 78, $13-25$.

[21] Goggi, A. S., Caragea, P., Pollak, L., MacAndrews, G., Devries, M. and Montgomery, K. (2008). Seed quality assurance in maize breeding programs: Tests to explain variations in maize inbreds andpopulations. Agronomy Journal, 100, 337-343. 
[22] Santos, B. (2010). Seed quality and seeding technology. Horticultural Sciences Department University of Florida Extension Bulletin Cooperative Extension Services. Florida, USA. : Institute of Food and Agricultural Sciences (IFAS).

[23] Schussler J. R, Westgate M. E. (1991). Maize kernel set at low water potential. 1. Sensitivity to reducedassimilates during early kernel growth. Crop Science, 31, 1189-1195.

[24] Çakir, R. (2004). Effect of water stress at different development stages on vegetative and reproductive growth of corn. Field Crops Research, 89: 1-16.

[25] Schär C, Vidale PL, Lüthi D, Frei C, Häberli C, Liniger MA, Appenzeller C. (2004). The role of increasing temperature variability in European summer heatwaves. Nature, 427, 332-336.

[26] Stratonovitch P, Semenov, M. A. (2015). Heat tolerance around flowering in wheat identified as a key trait for increased yield potential in Europe under climate change. Journal of Experimental Botany, 66(12), 3599-3609, doi:10.1093/jxb/erv070.

[27] Dore, M. (2005). Climate change and changes in global precipitation patterns: what do we know? Environ Int, 31, $1167-1181$.

[28] RStudio Team. (2015). RStudio: Integrated Development for R. RStudio, Inc., Boston, MA URL http://www.rstudio.com/.

[29] Romano-Armada N, Amoroso MJ, Rajal VB. (2017). Effect of glyphosate application on soil quality and health under natural and zero tillage field conditions. Soil Environment, 36(2), 141-154, DOI:10.25252/SE/17/51241.

[30] Mafongoya P, Jiri1 O, Phophi M. (2016). Evaluation of tillage practices for maize (Zea mays) grown on different land-Use systems in eastern Zambia. Sustainable Agriculture Research, 5(1): 10-23. 